\title{
Growth, Yield and Sucrose Percent Response of Sugarcane to Zinc and Boron Application
}

\section{Nadia Mangrio $^{1 *}$, Muhammad Nawaz Kandhro ${ }^{1}$, Aijaz Ahmed Soomro ${ }^{1}$, Nihaluddin Mari ${ }^{3}$ and Zia-ul- Hassan Shah ${ }^{2}$}

${ }^{1}$ Department of Agronomy, Sindh Agriculture University, Tandojam, Pakistan; ${ }^{2}$ Department of Soil Science; Sindh Agriculture University, Tandojam, Pakistan; ${ }^{3}$ Agriculture Research Centre, Tandojam, Pakistan.

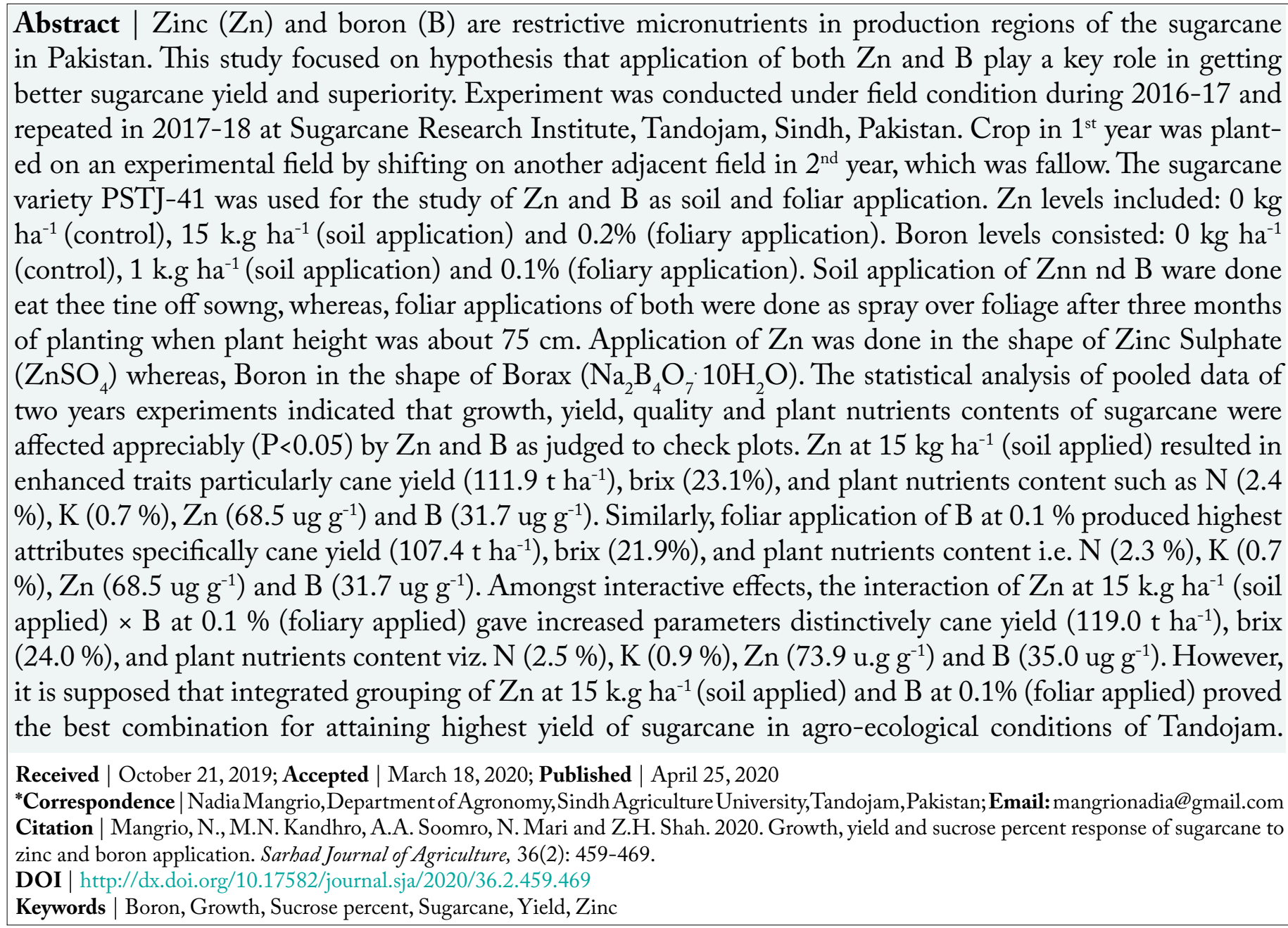

\section{Introduction}

Sugarcane (Saccharum officinarium L.) is a cash proSduce of our country (GoP, 2018). Sugarcane is also cultivated worldwide in more than 105 countries
(Hussain et al., 2015). According to area under cultivation, Pakistan is the $5^{\text {th }}$ position in cane acreage and production and almost $8^{\text {th }}$ biggest consumer of sugar in the world (FAO, 2017). Cane is the main and overwhelming raw material used. It could be a key June 2020 | Volume 36 | Issue 2 | Page 459 
source of profit and business for cultivating society of the nation (Ehsanullah et al., 2016). In our country area under cultivation of sugarcane is 1.131 million hectares and cane production of 73.6 million tonnes. Its surplus input inn agricultture end Gdp as 3.4 end 0.7 percant, correspondingly (GoP, 2017). Reason of sugarcane growing is to make sugar and sugary products (Naqvi, 2005). In Pakistan the average sugarcane yield is low as match up to other countries likes Australiia, Brazil, USA, China and India (MNFSR, 2013). Reasons of low yield include conventional planting methods, inappropriate seed rate, improper fertilizer application, poor irrigation management, insect pests, diseases, weeds, high cost of inputs, delayed harvesting, lack of agricultural education, credit shortage, natural calamities etc. (Baloch et al., 2002; Malik and Gurmani, 2005). Role of micronutrients is very important far grewth end developmnt of crop despite their requirements in a very minute quantity (Jabran et al., 2017). In the same way, Lifang et al. (2001) disclosed that inadequate supply of nutrients has greatest impact on reducing sugarcane yields. Sugarcane production and yield is considerably inclined by application of iron along with zinc. Quality traits i.e. sucrose \% revealed major variations upon the boron application at $10 \mathrm{~kg} \mathrm{ha} \mathrm{ha}^{-1}$ succeeded by $\mathrm{FeSO}_{4}$ spray $2 \%$ twofold after 30 and 60 days of sowing (Madhuri et al., 2016). Foliar applications are used to supply micronutrients more rapidly for correction of severe deficiencies and considered as a tool to improve nutrient-use efficiency (Jabran et al., 2017). Foliary appliction off $\mathrm{ZnSO} 40.5 \%$ made stride cane produce (Chandra, 2005). Ghaffar et al. (2011) stated that $\mathrm{Zn}$ and Fe application in count to macro-nutrients (NPK) has increased production of sugarcane. The present study was conducted by taking an account the significance of sugarcane and its response under micronutrients, the study was conductd to determine proper $\mathrm{Zn}$ and $\mathrm{B}$ requirements for enhanced growth, production and sucrose percentage of sugarcane within the agra-ecologcal condiitions off Tandjam.

\section{Materials and Methods}

The experimnt was undertaken to assess the consequence of foliar and soiil employed micronutrients ( $\mathrm{Zn}$ and $\mathrm{B}$ ) on growth, yield and sucrose percentage of sugarcane. Field area of Sugarcane Research Institute, Tandojam, Sindh, Pakistan was used for conducting experiments for two consecutive years during autumn 2016-17 and 2017-18. Thee soiil of trial region was clay loam, which acquiescent to USDA framework fit in to Order Aridisols and Subgroup Typic Camborthids. The experimental field was ploughed two times with disc harrow, irrigated, dried to workable condition, leveled and finally seedbed was prepared by plowing with cultivator. The experimnt was laid out under randomized complete block design (RCBD) having three replications. Plot size was $13 \mathrm{~m} \times 2.3 \mathrm{~m}\left(30 \mathrm{~m}^{2}\right)$. The crop in the $1^{\text {st }}$ year was planted on one plot of experimental field whereas during $2^{\text {nd }}$ year the crop was planted on adjacent fallow plot of same experimental field. The sugarcane candidate variety PSTJ-41 was planted on $22^{\text {nd }} 2016$ and $25^{\text {th }}$ September 2017, respectively. The field area was well managed prior to planting. After intense tillage operations with mould board plow, crosswise disc harrow, succeeded by rigorous smoothing was done to bring the soil to the condition suitable for cultivation. Ridger was used for making furrows. The experiment was comprised of three level of each $\mathrm{Zn}$ and $\mathrm{B}$. The suggested measurements of NPK fertilizers were also dispensed iin shape of Uria, DAP (diamonium phosphte) and SOP (sulphte of potesh). Al $\mathrm{P}$ end $\mathrm{K}$, end $1 / 3^{\text {rd }}$ of $\mathrm{N}$ ware used at the time of planting. The left over two splits of $\mathrm{N}$ were used at $1^{\text {st }}$ earthing-up $\left(3 \frac{1}{2}\right.$ months after sowing $)$ on $7^{\text {th }}$ January, 2017 and $9^{\text {th }}$ January 2018. In the same way second spilt dose was applied in next earthing-up (about 45 days after initial earthing up) on $23^{\text {rd }}$ February, 2017 and $24^{\text {th }}$ February 2018. All routine cultural practices like weeding, hoeing and herbicide application were kept common and consistent for all the plots. Applications of micronutrients $\mathrm{Zn}$ and $\mathrm{B}$ were done inn he farm of znc sulphte $(22 \% \mathrm{Zn})$ and Borax (11.36\% B). Zn and B (Soil application) were applied at the time of sowing at the amount of 15 and $1 \mathrm{k} . \mathrm{g}$ $\mathrm{ha}^{-1}$ in respective treatment plots while control plots got nothing. Appliction off $\mathrm{Zn}$ end $\mathrm{B}$ (foliar) at the requisite rates was sprayed on leaves at $75 \mathrm{~cm}$ height of crop on $23^{\text {rd }}$ December, 2016 and $22^{\text {nd }}$ December and 2017, correspondingly. $\mathrm{Zn}$ and B were sprayed at $0.2 \%$ and $0.1 \%$. The propagatory material was taken from upper $2 / 3^{\text {rd }}$ portion of stalk of eight months old cane. Cane setts were soaked in Topsin-M at $150 \mathrm{~g} 100^{-1} \mathrm{~L}$ water to protect them from many cane diseases like sugarcane smut. Dry method of planting was adopted for growing canes with ear-to-ear planting pattern. The cane setts were placed in furrows at depth of 6-8" and masked with 5-6 cm soil. Immediately after covering the setts water was let 
into furrows. Irrigation was applied keeping in view the soil condition and crop need as farmer practice. In summer (April-August) irrigation was applied at the interval of 7-10 days while in winter (November-March) at the interval of 10-15 days. Over all 28 irrigations have been implemented during the growing season (12 months). The herbicide (CLIO Combo pack at $3.75 \mathrm{k} . \mathrm{g} \mathrm{ha}{ }^{-1}$ was applied one month after planting when sufficient moisture was present in the soil. The insecticide Lorsban at $5 \mathrm{~L} \mathrm{ha}^{-1}$ was applied at $1^{\text {st }}$ irrigation to manipulate termites. Trichogramma cards were stapled against the borers. Insecticide Furadan 3G (Carbofuran) was televised at $30 \mathrm{~kg} \mathrm{ha}^{-1}$ in case borers were not controlled by Trichogramma cards. Harvesting was done when crop was physiologically mature i.e. ripening phase completed and brix was above $20 \%$. The crop was harvested manually on $28^{\text {th }}$ December, 2017 and $31^{\text {st }}$ December, 2018, respectively.

\section{Physico-chemical analysis of soil}

Thee soil samples were taken by hand auger at the profundity of $45 \mathrm{~cm}$ from five locations of experimental area earlier than planting and after reaping of crop. The samples had been air-dried, ground, sifted $(2 \mathrm{~mm})$ and placed in plastic containers. Later than various physical and chemical properties of soil were tested from these samples adopting procedure suggested by Rayan et al. (2001). Soil texture was measured by the Bouyoucos hydrometer method. Electrical conductivity (EC) and soil $\mathrm{pH}$ was measured in 1:2 soil/distilled water using $\mathrm{EC}$ and $\mathrm{pH}$ meters, respectively. Walkley and Black (1934) process was followed for the determination of organic matter content. Total $\mathrm{N}$ was calculated. However, soil was extracted for determining extractable $\mathrm{P}$ and $\mathrm{K}$ using Ammonium bicarbonate di-ethylene triamine penta acetic acid (AB-DTPA). B was determined by dry ashing in a muffle furnace (Bench Top Preiser, FB1410M) and measured colorimetrically by usage of azomethine- $\mathrm{H}$ (Keren, 1996). For Zn, the matrial wes wat assimilated in a 5:1 acid mixtre $\left(\mathrm{HNO}_{3}: \mathrm{HClO}_{4}\right)$, end th assimilate wes dilutd to $100 \mathrm{ml}$ wth distlled watar. $\mathrm{Zn}$ was measured by way of atomic absorption spectrophotometer (AA-7000, Shimadzu, Japan) (Wright and Stuczynski, 1996). The detals of physco-chemicl evaluation of soil are specified in Table 1.

\section{Statistical analysis}

Facts gathered from experiment was statistically analyzed by way of utilizing computur software Statistix

version 8.1 (Statistix, 2006). The difference between treatment means was evaluated by LSD test when $\mathrm{P}$ value was significant at alpha 0.05 .

\section{Table 1: Average physico-chemical properties of experimental soil (2016-17 and 2017-18).}

\section{Soil Parameter}

Soil texture

Sand (\%)

Silt (\%)

Clay (\%)

Textural class

Soil chemical analysis

EC $\left(\mathrm{dS} \mathrm{m}^{-1}\right)$

Soil pH

Organic matter (\%)

Total N (\%)

Available P $\left(\mathrm{mg} \mathrm{kg}^{-1}\right)$

Extractable K $\left(\mathrm{mg} \mathrm{kg}^{-1}\right)$

Extractable $\mathrm{Zn}\left(\mathrm{mg} \mathrm{kg}^{-1}\right)$

Extractable B $\left(\mathrm{mg} \mathrm{kg}^{-1}\right)$

\section{Results and Discussion}

\section{Bud sprouting (\%)}

Statistical evaluation of figures showed that signifcant $(p<0.05)$ effect was caused by $\mathrm{Zn}$ on sprouting of buds whereas, a non-signifcant $(p>0.05)$ by B and the interaction of $\mathrm{Zn}$ and $\mathrm{B}$ (Table 2). $\mathrm{Zn} 15 \mathrm{k.g} \mathrm{h}{ }^{-1}$ give the best sprouting of buds, accompanied via $0.2 \% \mathrm{Zn}$ foliar application having statistical equality with each other while lowest sprouting of buds was noticed in 0 $\mathrm{kg} \mathrm{ha}^{-1} \mathrm{Zn}$. Boron $1 \mathrm{~kg} \mathrm{ha}{ }^{-1}$ derivates greatest sprouting of buds seconded by $0.1 \% \mathrm{~B}$ foliar application and $0 \mathrm{~kg} \mathrm{~B} \mathrm{ha}{ }^{-1}$. The interaction of $\mathrm{Zn} 15 \mathrm{~kg} \mathrm{ha}^{-1} \times \mathrm{B} 1 \mathrm{~kg}$ $\mathrm{ha}^{-1}$ produced enhanced sprouting of buds preceded by $\mathrm{Zn} 15 \mathrm{~kg} \mathrm{ha}{ }^{-1} \times \mathrm{B} \quad 0.2 \%$ whereas diminished results were recorded in $\mathrm{Zn} 0 \mathrm{~kg} \mathrm{ha}^{-1} \times \mathrm{B} 0 \mathrm{~kg} \mathrm{ha}^{-1}$. This might be attributed to vital role of $\mathrm{Zn}$ in development and enhancement of sugarcane plants. The possible reason of better sprouting of buds with application of $\mathrm{Zn}$ might be fulfillment of plant requirement because mostly zinc stays bound to the solid particles of soil and exists in unavailable forms. Quantitative and qualitative parameters of sugarcane were significantly affected by different levels of $\mathrm{Zn}$ (Ghaffar et al., 2011). Jabran et al. (2017) revealed thet micronutrients $(\mathrm{Zn}$ and B) are also essential in plant improvement even though required in low extent. 
Weather data

Month Week

2016-17

Temperature $\left({ }^{\circ} \mathrm{C}\right) \quad$ Relative humid- Rainfall

Min. Max.

Sep. 16

$23.5 \quad 35.2$

Ii $\quad 23.2 \quad 36.0$

Iii $\quad 22.8 \quad 38.7$

Iv $\quad 22.6 \quad 37.2$

Oct.16 I $\quad 23.4 \quad 38.3$

$\begin{array}{lll}\text { Ii } & 21.5 & 37.3 \\ \text { Iii } & 19.6 & 36.6\end{array}$

$\begin{array}{lll}\text { Iii } & 19.6 & 36.6 \\ \text { Iv } & 18.9 & 36.1\end{array}$

$\begin{array}{lllll} & \text { Nov. } 16 \text { I } & 14.7 & 35.5 & 52.8\end{array}$

Ii $\quad 13.1 \quad 32.2 \quad 48.0$

Iii $\quad \begin{array}{lll}12.1 & 32.0 \quad 50.0\end{array}$

$\begin{array}{llll}\text { Iv } & 11.6 & 30.5 & 57.4\end{array}$

$\begin{array}{llll}\text { Dec. } 16 \text { I } & 12.1 & 30.3 & 52.6\end{array}$

$\begin{array}{llll}\text { Ii } & 12.8 & 28.1 & 60.0\end{array}$

Iii $\quad 10.4 \quad 27.8 \quad 49.9$

Iv $\quad 9.6 \quad 27.9 \quad 57.4$

$\begin{array}{lllll}\text { Jan. } 17 & \text { I } & 9.0 & 20.8 & 71.5\end{array}$

$\begin{array}{llll}\text { Ii } & 6.1 & 21.3 & 58.7\end{array}$

$\begin{array}{llll}\text { Iii } & 6.4 & 21.9 & 55.2\end{array}$

Iv $\quad 7.3 \quad 24.3 \quad 57.6$

Feb. 17

I $\quad 8.6 \quad 24.6$

Ii $\quad 7.7 \quad 26.1$

Iii $\quad 12.6 \quad 30.2$

iv $\quad 10.9 \quad 31.7$

Mar. 17 i $\quad 11.7 \quad 31.6$

ii $\quad 10.8 \quad 30.6$

iii $\quad 16.1 \quad 34.7$

iv $\quad 18.7 \quad 39.8$

Apr. 17 i $\quad 19.4 \quad 38.6$

ii $\quad 16.7 \quad 42.9$

iii $\quad 21.2 \quad 40.4$

iv $\quad 22.0 \quad 38.9$

May. 17 i $\quad 22.1 \quad 42.2$

ii $\quad 24.2 \quad 41.8$

iii $\quad 24.5 \quad 40.5$

iv $\quad 25.9 \quad 41.9$

Jun. 17 i $\quad 25.5 \quad 40.0$

ii $\quad 26.1 \quad 39.7$

iii $\quad 26.1 \quad 38.6$

iv $\quad 26.5 \quad 38.9$

Jul. 17 i $\quad 25.6 \quad 37.3$

ii $\quad 25.2 \quad 37.2$

iii $\quad 25.0 \quad 36.6$

iv $\quad 25.4 \quad 35.7$

Aug. $17 \mathrm{i} \quad 25.1 \quad 35.8$

ii $\quad 24.8 \quad 35.9$

iii $\quad 24.6 \quad 37.5$

iv $\quad 24.7 \quad 36.2$

Sep. 17 i $\quad 24.1 \quad 35.0$

ii $\quad 23.1 \quad 35.6$

iii $\quad 23.2 \quad 37.9$

iv $\quad 21.9 \quad 36.5$

Oct. 17 i

$\begin{array}{ll}21.9 & 36.5 \\ 20.8 & 37.8\end{array}$

ii $\quad 19.4 \quad 39.6$

iii $\quad 19.3 \quad 39.0$

37.2
( $\quad(\mathrm{mm})$

52.0

45.7

50.4

47.1

46.7

42.8

50.6

46.7

42.5

34.1

45.7

46.2

46.6

49.5

48.8

55.6

60.6

57.5

60.7

62.4

64.8

64.5

70.7

69.3

67.5

65.0

63.0

68.5

68.5

70.4

62.6

61.7

58.0

51.0

48.8

55.0

0.0

0.0

0.0

0.0

0.0

0.0

0.0

0.0

0.0

0.0

0.0

0.0

0.0

0.0

0.0

0.0

0.0

0.1

0.0

0.3

0.0

0.0

0.0

0.0

0.0

0.0

0.0

0.0

0.0
0.0

0.0

0.0

0.0

0.0

0.0

0.0

0.0

0.0

0.0

0.7

0.0

0.8

1.4

0.3

0.0

0.0

0.4

10.0

0.0

0.0

0.0

0.0

0.0

0.0

0.0

0.0
Month Week

2017-18

Temperature $\left({ }^{\circ} \mathrm{C}\right)$

Min. Max.

$15.9 \quad 35.4 \quad 51.3$

Nov. 17 i

$13.4 \quad 32.0$

55.9

48.3

$\begin{array}{lll}\text { iii } & 9.9 & 27.0 \\ \text { iv } & 10.7 & 30.4\end{array}$

Dec. 17 i $\quad 8.5 \quad 25.1$

$\begin{array}{lll}\text { ii } & 8.5 & 25.1 \\ \text { iil } & 8.6 & 22.9\end{array}$

$\begin{array}{lll}\text { iii } & 8.4 & 24.9 \\ \text { iv } & 7.1 & 25.9\end{array}$

Jan. 18

i

5.0

25.9
25.5

ii $\quad 8.6 \quad 25.7$

iii $\quad 9.1 \quad 26.3$

iv $\quad 9.3 \quad 28.1$

Feb. 18 i $\quad 10.1 \quad 25.4$

ii $\quad 10.4 \quad 26.2$

iii $\quad 11.7 \quad 32.1$

iv $\quad 15.2 \quad 31.4$

Mar. 18 i $\quad 15.4 \quad 34.3$

ii $\quad 16.2 \quad 34.8$

iii $\quad 15.1 \quad 34.8$

iv $\quad 16.1 \quad 40.6$

Apr. $18 \quad \mathrm{i}$

$19.5 \quad 39.9$

ii $\quad 20.3 \quad 39.7$

iii $\quad 19.3 \quad 38.8$

iv $\quad 21.4 \quad 42.7$

$23.3 \quad 40.9$

ii $\quad 23.8 \quad 41.9$

iii 23.3

iv $\quad 23.8$

41.9

43.3

Jun. 18 i

i 25.5

40.6
39.2

$\begin{array}{lll}\text { iii } & 26.1 & 39.2 \\ & 25.5 & 39.1\end{array}$

iv $\quad 24.9 \quad 37.2$

Jul. 18 i $\quad 25.6 \quad 38.3$

ii $\quad 25.5 \quad 37.0$

iii $\quad 25.1 \quad 36.4$

iv $\quad 24.8 \quad 36.4$

Aug. 18 i $\quad 24.2 \quad 36.0$

ii $\quad 24.5 \quad 35.2$

iii $\quad 24.1 \quad 36.3$

iv $\quad 23.0 \quad 36.3$

Sep. 18 i $\quad 22.4 \quad 36.1$

ii $\quad 22.9 \quad 35.2$

iii $\quad 21.8 \quad 37.2$

iv $\quad 22.8 \quad 38.8$

Oct. 18 i $\quad 20.0 \quad 40.2$

35.6

ii $\quad 18.1 \quad 35.6$

iii $\quad \begin{array}{ll}17.5 & 35.9\end{array}$

iv $\quad 16.8 \quad 37.9$

Nov. 18 i $\quad 14.4 \quad 32.9$

ii $\quad 15.3 \quad 32.5$

iii $\quad 15.3 \quad 30.9$

iv $\quad 14.8 \quad 30.1$

Dec. 18 i

$\begin{array}{lll}\text { i } & 13.3 & 29.5 \\ \text { ii } & 11.1 & 24.9\end{array}$

iii $\quad 6.8 \quad 24.0$

iv $\quad 6.5 \quad 25.4$

48.6

46.6

58.7

54.1

50.2

50.7

50.2

52.2

52.1

48.4

48.2

50.4

58.1

52.8

49.1

45.1

35.7

46.1

43.0

33.7

44.5

48.4

44.1

31.6

41.0

52.4

57.7

56.9

63.9

59.8

62.0

68.6

63.0

61.8

68.7

66.6

63.5

63.1

63.0

59.1

57.1

57.3

49.4

45.8

48.9

47.3

59.4

59.9

60.8

61.3

63.9

57.9

55.6
Relative hu-

Rainfall

May. 18 i 
Plant population (000 $\left.\mathrm{ha}^{-1}\right)$

Analysis of variance showed that a considerable $(p<0.05)$ result was induced by $\mathrm{Zn}$ on plant population $\left(000 \mathrm{~h}^{-1}\right)$ while, nan-signifcant $(p>0.05)$ be $\mathrm{B}$ and intraction (Table 2). $\mathrm{Zn} 15 \mathrm{~kg} \mathrm{ha}^{-1}$ gave most productive plant population followed by $0.2 \% \mathrm{Zn}$ foliar application having statistical parallelism with each other while lowest plant population was noticed in $0 \mathrm{~kg} \mathrm{ha}^{-1} \mathrm{Zn}$, where $\mathrm{Zn}$ was not applied. Boron $1 \mathrm{~kg}$ $\mathrm{ha}^{-1}$ resulted in best plant population followed by $0.1 \%$ $\mathrm{B}$ foliar application and $0 \mathrm{~kg} \mathrm{~B} \mathrm{ha}{ }^{-1}$. The interaction of $\mathrm{Zn} 15 \mathrm{~kg} \mathrm{ha}^{-1} \times \mathrm{B} 1 \mathrm{~kg} \mathrm{ha}^{-1}$ produced improved plant population lead by $\mathrm{Zn} 15 \mathrm{~kg} \mathrm{ha}{ }^{-1} \times \mathrm{B} 0.2 \%$ whereas reduced results were recorded in $\mathrm{Zn} 0 \mathrm{~kg} \mathrm{ha}^{-1}$ $\times \mathrm{B} 0 \mathrm{~kg} \mathrm{ha} \mathrm{h}^{-1}$ that contrasted considerably from all other treatments. The reason behind improved plant population might be due to the essential role of Zinc in a broad variety of biochemical processes that have an effect on growth, development, and reproduction and almost all characteristics of cellular metabolism. These results are in uniformity with Wang et al. (2005) who evaluated the best possible rate of $\mathrm{Zn}$ application for sugarcane production and specified that $\mathrm{Zn}$ in the form of $\mathrm{ZnSO}_{4}$ can considerably promote sugarcane production.

\section{Crop growth rate $\left(\mathrm{g} \mathrm{m}^{-2}\right.$ day $\left.{ }^{-1}\right)$}

Facts concerning crop growth rate $\left(\mathrm{g} \mathrm{m}^{-2}\right.$ day $\left.^{-1}\right)$ exhibited noteworthy $(\mathrm{p}<0.05)$ effect by $\mathrm{Zn}$ and $\mathrm{B}$ and non-signifcant $(p>0.05)$ by interaction (Table 3$)$. $\mathrm{Zn}$ $15 \mathrm{k} . \mathrm{g} \mathrm{h}^{-1}$ resulted in increased crp grwth rat preceded by $0.2 \% \mathrm{Zn}$ foliar application having statistical equivalence with each other while lowest crop growth rate was noticed in $0 \mathrm{k} . \mathrm{g} \mathrm{h}^{-1} \mathrm{Zn} .0 .1 \% \mathrm{~B}$ folar appliction resulted in greatest crop growth rate next to Boron 1 k.g h ${ }^{-1}$ and $0 \mathrm{k} . g \mathrm{~B} \mathrm{ha}^{-1}$. The interaction of $\mathrm{Zn} 15 \mathrm{k} . \mathrm{g}$ $\mathrm{h}^{-1} \times \mathrm{B} 1 \mathrm{k} \cdot \mathrm{g} \mathrm{h}^{-1}$ produced amended crop growth rate follwed by $\mathrm{Zn} 15 \mathrm{k} \cdot \mathrm{g} \mathrm{h}^{-1} \times \mathrm{B} 0.1 \%$ whereas weak results were examined in $\mathrm{Zn} 0 \mathrm{~kg} \mathrm{ha}^{-1} \times \mathrm{B} 0 \mathrm{~kg} \mathrm{ha}^{-1}$. The reason behind enhanced crop grwth rat could be due to the foliar application of zinc that increases the enzymes activity and leads to easy translocation of assimilate from leaf to grain. These results are further invigorated by Panhwar et al. (2003) who reported that foliar application of zinc sulfate had more useful outcomes than soil application when farm yard manure, quite well rotten sheep or goat manure at the time of land preparation is assimilated.

\section{Leaf area $\left(\mathrm{cm}^{2}\right)$}

Leaf area $\left(\mathrm{cm}^{2}\right)$ responded significantly $(p<0.05)$ to $\mathrm{Zn}, \mathrm{B}$ and their interaction (Table 3). Zn $15 \mathrm{~kg} \mathrm{ha}^{-1}$ gave dynamic leaf area followed by $0.2 \% \mathrm{Zn}$ foliar application having statistical evenhandedness with each other while lowest leaf area was noticed in $0 \mathrm{~kg}$ $\mathrm{ha}^{-1} \mathrm{Zn}$. Boron $0.1 \%$ foliar application profoundly enhanced the leaf area followed by $1 \mathrm{~kg} \mathrm{ha}^{-1} \mathrm{~B}$ and $0 \mathrm{~kg}$ $\mathrm{B} \mathrm{ha}^{-1}$. The interaction of $\mathrm{Zn} 15 \mathrm{~kg} \mathrm{ha} \mathrm{h}^{-1} \times \mathrm{B} 1 \mathrm{~kg} \mathrm{ha} \mathrm{ha}^{-1}$ produced superior leaf area pursued by $\mathrm{Zn} 15 \mathrm{~kg} \mathrm{ha}^{-1}$ $\times \mathrm{B} 0.1 \%$ whereas dwindled results were recorded in $\mathrm{Zn} 0 \mathrm{~kg} \mathrm{ha}^{-1} \times \mathrm{B} 0 \mathrm{~kg} \mathrm{ha}{ }^{-1}$. The possible reason of superior leaf area with application of $\mathrm{Zn}$ might be due to its performance in the vital plant capabilities like photosynthesis, protein and chlorophyll production.

\section{Cane length $(\mathrm{cm})$}

Cane length is a prime yield supervening part in sugarcane. Statistical analysis of data showed that significant $(p<0.05)$ effect on cane length $(\mathrm{cm})$ was caused by $\mathrm{Zn}$ and $\mathrm{B}$ and none-signifcant $(p>0.05)$ by interaction (Table 4). $\mathrm{Zn} 15 \mathrm{~kg} \mathrm{ha}^{-1}$ gave vigorous cane length followed by $0.2 \% \mathrm{Zn}$ foliar application having statistical equality with each other while declined cane length was seen in $0 \mathrm{k} . g \mathrm{ha}^{-1} \mathrm{Zn}$. Boron $0.1 \%$ foliar application produced greatest cane length seconded by $1 \mathrm{k} \cdot \mathrm{g} \mathrm{ha} \mathrm{g}^{-1} \mathrm{~B}$ and $0 \mathrm{~kg} \mathrm{~B} \mathrm{ha}{ }^{-1}$. The interaction of $\mathrm{Zn} 15 \mathrm{~kg} \mathrm{ha}^{-1} \times \mathrm{B} 1 \mathrm{~kg} \mathrm{ha}^{-1}$ revealed improved cane length headed by $\mathrm{Zn} 15 \mathrm{k} \cdot \mathrm{g} \mathrm{h}^{-1} \times \mathrm{B} 0.1 \%$ whereas moderate results were recorded in $\mathrm{Zn} 0 \mathrm{~kg} \mathrm{ha}^{-1} \times \mathrm{B} 0$ $\mathrm{kg} \mathrm{ha} \mathrm{h}^{-1}$. The increse in cene langth may be endorsed to additional vegetative growth due to availability of balanced $\mathrm{Zn}$ application because $\mathrm{Zn}$ plays a major part in the production of growth substances. Parallel outcomes were quoted by Mariano et al. (2011) who reported that stalk technological quality improved with $\mathrm{Zn}$ fertilization, furthermore it is providing residual effect as well as increasing the above ground biomass. Khan et al. (1997) and Soomro et al. (2005) also reported that plant height was improved due to foliar application of micronutrients over the control treatment.

\section{Cane girth $(\mathrm{cm})$}

Canee girtth $(\mathrm{cm})$ become affected significantly $(p>0.05)$ by $\mathrm{Zn}$ and B but there interacton was appeared to be non-significant (Table 4). Zn $15 \mathrm{~kg}$ $\mathrm{ha}^{-1}$ accorded highest cane girth followed by $0.2 \%$ $\mathrm{Zn}$ foliar application having statistical egalitarianism with each other while lowest cane girth was observed in $0 \mathrm{~kg} \mathrm{ha}^{-1} \mathrm{Zn}$. Boron $1 \mathrm{~kg} \mathrm{ha}{ }^{-1}$ and $0.1 \%$ foliar application resulted in greatest cane girth succeeding by $0 \mathrm{~kg} \mathrm{~B} \mathrm{ha-1}$. The interaction of $\mathrm{Zn} 15 \mathrm{~kg} \mathrm{ha}^{-1} \times \mathrm{B}$ $1 \mathrm{~kg} \mathrm{ha}{ }^{-1}$ produced better cane girth preceded by $\mathrm{Zn}$ $15 \mathrm{k} . g \mathrm{~h}^{-1} \times \mathrm{B} 0.1 \%$ whereas shortest cane girth was 
observed in $\mathrm{Zn} 0 \mathrm{~kg} \mathrm{ha}^{-1} \times \mathrm{B} 0 \mathrm{~kg} \mathrm{ha}{ }^{-1}$. The results showed that when $\mathrm{Zn}$ was added in the nutrient program, a noticeable increase in the cane girth was observed. Although, the effect of boron on cane girth was also seen, but in fact there was petite need of boron was seemed. The results have similarities with thee findings of Naemat et al. (1992) and Khan et al. (1997) who confirmed that with the foliar application of micronutrients there was crucial enhancement in cane diameter.

\section{Tillers stool ${ }^{-1}$}

Effacts of $\mathrm{Zn}$ and B ware signifcant $(p<0.05)$ for the tillers stool ${ }^{-1}$ whereas interactive effects of the treatmnts were fond to be non- signifcant (Table 5). $\mathrm{Zn} 15$ $\mathrm{kg} \mathrm{ha}^{-1}$ gave highest tillers stool ${ }^{-1}$ followed by $0.2 \% \mathrm{Zn}$ foliar application having statistical equality with each other while lowest tillers stool ${ }^{-1}$ was seen in $0 \mathrm{k.g} \mathrm{ha}{ }^{-1}$ $\mathrm{Zn}$. Boron $0.1 \%$ foliar application resulted in greatest tillers stool ${ }^{-1}$ seconded by $1 \mathrm{k} . \mathrm{g} \mathrm{ha} \mathrm{h}^{-1} \mathrm{~B}$ and $0 \mathrm{~kg} \mathrm{~B} \mathrm{ha}{ }^{-1}$. The interaction of $\mathrm{Zn} 15 \mathrm{~kg} \mathrm{ha}^{-1} \times \mathrm{B} 1 \mathrm{~kg} \mathrm{ha}^{-1}$ exposed improved tillers stool ${ }^{-1}$ headed by $\mathrm{Zn} 15 \mathrm{k} \cdot \mathrm{g} \mathrm{h}^{-1} \times \mathrm{B}$ $0.1 \%$ whereas moderate results had been recorded in $\mathrm{Zn} 0 \mathrm{~kg} \mathrm{ha}{ }^{-1} \times \mathrm{B} 0 \mathrm{~kg} \mathrm{ha}^{-1}$. The improved tillers stool ${ }^{-1}$ possibly will be due to the role of $\mathrm{Zn}$ to play an vital role in a wide range of processes, such as growth hormone production and internode elongation. The reslts are well supported by the findings of Shafique (2015) who described that with the increased number of zinc levels, number of tillers also increased simultaneously; though application of boron did not show clear consequences on the number of tillers stool ${ }^{-1}$ in sugarcane.

\section{Internodes cane $e^{-1}$}

Figures given in Table 5 exposed that effect of $\mathrm{Zn}$ and $\mathrm{B}$ was signifcant $(p<0.05)$ forr internodes cane $\mathrm{c}^{-1}$ while their interaction was non- significant (Table 5). Zn $15 \mathrm{~kg} \mathrm{ha}^{-1}$ gave utmost internodes cane ${ }^{-1}$ followed by $0.2 \% \mathrm{Zn}$ foliar application having statistical equality with each other while lowest internodes cane $^{-1}$ was observed in $0 \mathrm{k} . \mathrm{g} \mathrm{ha}{ }^{-1} \mathrm{Zn}$. Boron $0.1 \%$ foliar application resulted in greatest internodes cane $^{-1}$ followed by $1 \mathrm{k} \cdot g \mathrm{ha}^{-1} \mathrm{~B}$ and $0 \mathrm{~kg} \mathrm{~B} \mathrm{ha} \mathrm{h}^{-1}$. The interaction of $\mathrm{Zn} 15 \mathrm{~kg} \mathrm{ha}^{-1} \times \mathrm{B} 1 \mathrm{~kg} \mathrm{ha}^{-1}$ produced improved internodes cane ${ }^{-1}$ lead by $\mathrm{Zn} 15 \mathrm{k} \cdot \mathrm{g} \mathrm{h}^{-1} \times \mathrm{B}$ $0.1 \%$ whereas reduced results were recorded in $\mathrm{Zn} 0$ $\mathrm{kg} \mathrm{ha} \mathrm{g}^{-1} \times \mathrm{B} 0 \mathrm{~kg} \mathrm{ha}^{-1}$. The possible reason of superior internodes cane ${ }^{-1}$ with application of Zinc might be due to its involvement in formation of chlorophyll and carbohydrate. The reslts or an uniformity with Ghaffar et al. (2012) who explained that with the application of $\mathrm{Zn}$, quantitative parameters of sugarcane including cane diameter, number of internodes and stripped cane weight were affected significantly. Soomro et al. (2005) also reported that with the foliar feeding of micronutrients, mor number of internodes per stalk were examined with over control.

\section{Millable canes $\left(000 \mathrm{ha}^{-1}\right)$}

Numbr of milable cane per uniit ara is one of the foremost yield issues of sugarcne on which the yield depands. Millable canes $\left(000 \mathrm{~h}^{-1}\right)$ were effected significntly $(p<0.05)$ by $\mathrm{Zn}$ and $\mathrm{B}$ but there interacton wass noted nan-signifcant $(p>0.05)$ (Table 6). Zn 15 $\mathrm{kg} \mathrm{ha}{ }^{-1}$ gave maximum millable canes followed by $0.2 \% \mathrm{Zn}$ foliar application having statistical equality with each other while lowest millable canes was noticed in $0 \mathrm{k.g} \mathrm{h}{ }^{-1} \mathrm{Zn}$. Boron $0.1 \%$ foliary applicaton resultd in greatest millable canes followed by $1 \mathrm{k.g} \mathrm{h} \mathrm{h}^{-1}$ $\mathrm{B}$ and $0 \mathrm{~kg} \mathrm{~B} \mathrm{ha} a^{-1}$. The interaction of $\mathrm{Zn} 15 \mathrm{~kg} \mathrm{ha}^{-1} \times$ B $1 \mathrm{~kg} \mathrm{ha}^{-1}$ produced improved millable canes lead by Zn $15 \mathrm{k.g} \mathrm{h} \mathrm{h}^{-1} \times \mathrm{B} 0.1 \%$ whereas reduced results were recorded in $\mathrm{Zn} 0 \mathrm{~kg} \mathrm{ha} \mathrm{h}^{-1} \times \mathrm{B} 0 \mathrm{~kg} \mathrm{ha}^{-1}$. The promising reason of superior millable canes with application of $\mathrm{Zn}$ might be due to its fundamental role plant functions like photosynthesis, protein and chlorophyll synthesis. The data of our experiment indicated that $\mathrm{Zn}$ at $15 \mathrm{~kg} \mathrm{ha}^{-1}$ significantly affect the number of millable canes of the crop. As reported by Tunio et al. (2004) that increasing rate of $\mathrm{Zn}$ was inversely proportional to the average number of millable canes.

\section{Cane yield $\left(t h a^{-1}\right)$}

Cane yield $\left(\mathrm{t} \mathrm{ha}^{-1}\right)$ was signifcant $(p<0.05)$ regarding $\mathrm{Zn}$ and $\mathrm{B}$ effects, however, interactive effects were also significant (Table 6). Under Zn $15 \mathrm{~kg} \mathrm{ha}^{-1}$ maximum cane yield was observed, along with $0.2 \% \mathrm{Zn}$ foliar application having statistical impartiality with each other while lowest cane yield was noticed in 0 $\mathrm{k.g} \mathrm{h} \mathrm{h}^{-1} \mathrm{Zn}$. Boron $0.1 \%$ foliar application resulted in greatest cane yield followed by $1 \mathrm{k} \cdot g \mathrm{~h}^{-1} \mathrm{~B}$ and $0 \mathrm{~kg} \mathrm{~B}$ $\mathrm{ha}^{-1}$. The interaction of $\mathrm{Zn} 15 \mathrm{~kg} \mathrm{ha}^{-1} \times \mathrm{B} 0.1 \%$ produced improved cane yield lead by $\mathrm{Zn} 15 \mathrm{~kg} \mathrm{ha}^{-1} \times \mathrm{B}$ $1 \mathrm{~kg} \mathrm{ha}^{-1}$ whereas reduced results were recorded in $\mathrm{Zn}$ $0 \mathrm{~kg} \mathrm{ha}^{-1} \times \mathrm{B} 0 \mathrm{~kg} \mathrm{ha}^{-1}$. The results proved that when $\mathrm{Zn}$ was applied a noticeable improvement in the cane yield occurred, which enhanced the number of shoots and millable canes in the treated plots significantly. Similarly, Rohtash and Singh (1997) alsoo reportad that $\mathrm{Zn}$ application at $25 \mathrm{~kg} \mathrm{ZnSO}_{4} \mathrm{ha}^{-1}$ increased cane yield which mght be due to the favurable effect of $\mathrm{Zn}$ on the biosynthesis of plant hormone, Indole Acetic Acid, which in turn increased the plant height, number of internodes and millable canes. 
Table 2: Bud sprouting (\%) and plant population $\left(000 \mathrm{ha}^{-1}\right)$ of sugarcane as affected by $\mathrm{Zn}$ and B application.

\begin{tabular}{|c|c|c|c|c|c|c|c|c|}
\hline \multirow[t]{3}{*}{ Zinc levels } & \multicolumn{4}{|c|}{ Bud sprouting (\%) } & \multicolumn{4}{|c|}{ Plant population $\left(000 \mathrm{ha}^{-1}\right)$} \\
\hline & \multicolumn{4}{|c|}{ Boron levels } & \multicolumn{4}{|c|}{ Boron levels } \\
\hline & $0 \mathrm{~kg} \mathrm{ha}^{-1}$ & $1 \mathrm{~kg} \mathrm{ha}^{-1}$ & $0.1 \%$ & Mean & $0 \mathrm{~kg} \mathrm{ha}^{-1}$ & $1 \mathrm{~kg} \mathrm{ha}^{-1}$ & $0.1 \%$ & Mean \\
\hline $0 \mathrm{~kg} \mathrm{ha}^{-1}$ & 64.3 & 71.3 & 71.7 & $69.1 \mathrm{~b}$ & 63.7 & 67.0 & 70.7 & $67.1 \mathrm{~b}$ \\
\hline $15 \mathrm{~kg} \mathrm{ha}^{-1}$ & 80.0 & 84.3 & 82.7 & $82.3 \mathrm{a}$ & 76.0 & 82.7 & 77.0 & $78.6 \mathrm{a}$ \\
\hline $0.2 \%$ & 74.7 & 80.7 & 81.0 & $78.8 \mathrm{a}$ & 74.7 & 75.3 & 76.0 & $75.3 \mathrm{a}$ \\
\hline Mean & 73.0 & 78.8 & 78.5 & - & 71.5 & 75.0 & 74.6 & - \\
\hline Variables & S.E & $p$-value & LSD (5\% & & S.E & & $p^{\text {-value }}$ & LSD (5\%) \\
\hline Zn levels & 3.8740 & 0.0099 & 8.2126 & & 2.8523 & & 0.0030 & 6.0467 \\
\hline B levels & 3.8740 & 0.2747 & - & & 2.8523 & & 0.4176 & - \\
\hline $\mathrm{Zn} \times \mathrm{B}$ & 6.7100 & 0.9907 & - & & 4.9404 & & 0.6755 & - \\
\hline
\end{tabular}

Table 3: Crop growth rate $\left(\mathrm{g} \mathrm{m}^{-2}\right.$ day $\left.{ }^{-1}\right)$ and leaf area $\left(\mathrm{cm}^{2}\right)$ of sugarcane as affected by $\mathrm{Zn}$ and B application.

\begin{tabular}{|c|c|c|c|c|c|c|c|c|}
\hline \multirow[t]{3}{*}{ Zinc levels } & \multicolumn{4}{|c|}{ Crop growth rate $\left(\mathrm{g} \mathrm{m}^{-2}\right.$ day $\left.^{-1}\right)$} & \multicolumn{4}{|c|}{ Leaf area $\left(\mathrm{cm}^{2}\right)$} \\
\hline & \multicolumn{4}{|c|}{ Boron levels } & \multicolumn{4}{|c|}{ Boron levels } \\
\hline & $0 \mathrm{~kg} \mathrm{ha}^{-1}$ & $1 \mathrm{~kg} \mathrm{ha}^{-1}$ & $0.1 \%$ & Mean & $0 \mathrm{~kg} \mathrm{ha}^{-1}$ & $1 \mathrm{~kg} \mathrm{ha}^{-1}$ & $0.1 \%$ & Mean \\
\hline $0 \mathrm{~kg} \mathrm{ha}^{-1}$ & 5.1 & 5.7 & 6.1 & $5.6 \mathrm{c}$ & $452.7 \mathrm{f}$ & $476.0 \mathrm{f}$ & $553.7 \mathrm{e}$ & $494.1 \mathrm{c}$ \\
\hline $15 \mathrm{~kg} \mathrm{ha}^{-1}$ & 7.4 & 9.4 & 8.8 & $8.5 \mathrm{a}$ & $641.3 \mathrm{~d}$ & $893.7 \mathrm{a}$ & $827.0 \mathrm{~b}$ & $787.3 \mathrm{a}$ \\
\hline $0.2 \%$ & 6.6 & 7.6 & 8.5 & $7.6 \mathrm{~b}$ & $595.3 \mathrm{de}$ & $722.3 \mathrm{c}$ & $752.0 \mathrm{c}$ & $689.9 \mathrm{~b}$ \\
\hline Mean & $6.4 \mathrm{~B}$ & $7.6 \mathrm{a}$ & $7.8 \mathrm{a}$ & - & $563.1 \mathrm{~B}$ & $697.3 \mathrm{a}$ & $710.9 \mathrm{a}$ & - \\
\hline Variables & S.E & & $p$-value & LSD (5\%) & S.E & & $p$-value & LSD (5\%) \\
\hline Zn levels & 0.3004 & & 0.0000 & 0.6369 & 14.729 & & 0.0000 & 31.224 \\
\hline B levels & 0.3004 & & 0.0004 & 0.6369 & 14.729 & & 0.0000 & 31.224 \\
\hline $\mathrm{Zn} \times \mathrm{B}$ & 0.5204 & & 0.1995 & - & 25.511 & & 0.0002 & 54.082 \\
\hline
\end{tabular}

Table 4: Cane length (cm) and cane girth (cm) of sugarcane as affected by $\mathrm{Zn}$ and B application.

Zinc levels

\begin{tabular}{llll} 
& & \multicolumn{3}{c}{ Boron levels } \\
& $\mathbf{0 ~ k g ~ h a} \mathbf{~ h ~ h a ~}^{-1}$ & $\mathbf{1} \mathbf{~ k ~ h a ~}^{-1}$ & $\mathbf{0 . 1 \%}$ \\
$\mathrm{kg} \mathrm{hg} \mathrm{ha}^{-1}$ & 160.7 & 188.7 & 218.7 \\
$0.2 \%$ & 289.0 & 343.3 & 327.0 \\
Mean & 258.3 & 300.7 & 310.3 \\
Variables & $236.0 \mathrm{~b}$ & $277.6 \mathrm{a}$ & $285.3 \mathrm{a}$ \\
Zn levels & $\mathrm{S} . \mathrm{E}$ & & $\boldsymbol{P}^{\text {-value }}$ \\
B levels & 8.9764 & & 0.0000 \\
Zn $\times \mathrm{B}$ & 8.9764 & & 0.0001 \\
& 15.548 & & 0.3779
\end{tabular}

Cane length $(\mathrm{cm})$

Table 5: Tillers stool ${ }^{-1}$ and internodes cane $e^{-1}$ of sugarcane as affected by Zn and B application.

\section{Zinc levels}

Tillers stool ${ }^{-1}$

Boron levels

\begin{tabular}{|c|c|c|c|c|c|c|c|c|}
\hline & \multicolumn{4}{|c|}{ Boron levels } & \multicolumn{4}{|c|}{ Boron levels } \\
\hline & $0 \mathrm{~kg} \mathrm{ha}^{-1}$ & $1 \mathrm{~kg} \mathrm{ha}^{-1}$ & $0.1 \%$ & Mean & $0 \mathrm{~kg} \mathrm{ha}^{-1}$ & $1 \mathrm{~kg} \mathrm{ha}^{-1}$ & $0.1 \%$ & Mean \\
\hline $0 \mathrm{~kg} \mathrm{ha} \mathrm{h}^{-1}$ & 4.7 & 5.0 & 5.3 & $5.0 \mathrm{~b}$ & 20.3 & 22.3 & 25.0 & $22.5 \mathrm{c}$ \\
\hline $15 \mathrm{~kg} \mathrm{ha}^{-1}$ & 5.7 & 7.7 & 7.3 & $6.9 \mathrm{a}$ & 28.7 & 35.3 & 32.7 & $32.2 \mathrm{a}$ \\
\hline $0.2 \%$ & 5.7 & 6.3 & 7.0 & $6.3 \mathrm{a}$ & 25.7 & 29.3 & 31.3 & $28.8 \mathrm{~b}$ \\
\hline Mean & $5.4 \mathrm{~b}$ & $6.3 \mathrm{a}$ & $6.5 \mathrm{a}$ & - & $24.9 \mathrm{~b}$ & $29.0 \mathrm{a}$ & $29.7 \mathrm{a}$ & - \\
\hline Variables & S. E & & $p$-value & LSD (5\%) & S. E & & $p$-value & LSD (5\%) \\
\hline Zn levels & 0.3318 & & 0.0001 & 0.7034 & 1.1449 & & 0.0000 & 2.4270 \\
\hline B levels & 0.3318 & & 0.0045 & 0.7034 & 1.1449 & & 0.0014 & 2.4270 \\
\hline $\mathrm{Zn} \times \mathrm{B}$ & 0.5747 & & 0.3089 & - & 1.9830 & & 0.3300 & - \\
\hline
\end{tabular}

Internodes cane ${ }^{-1}$

Boron levels

June 2020 | Volume 36 | Issue 2 | Page 465

Cane girth $(\mathrm{cm})$

Boron levels

\begin{tabular}{|c|c|c|c|c|}
\hline Mean & $0 \mathrm{~kg} \mathrm{ha}^{-1}$ & $1 \mathrm{~kg} \mathrm{ha}^{-1}$ & $0.1 \%$ & Mean \\
\hline $189.4 \mathrm{c}$ & 2.2 & 2.2 & 2.3 & $2.2 \mathrm{c}$ \\
\hline $319.8 \mathrm{a}$ & 2.5 & 2.9 & 2.8 & $2.7 \mathrm{a}$ \\
\hline $289.8 \mathrm{~b}$ & 2.5 & 2.6 & 2.7 & $2.6 \mathrm{~b}$ \\
\hline - & $2.4 \mathrm{~b}$ & $2.6 \mathrm{a}$ & $2.6 \mathrm{a}$ & - \\
\hline LSD (5\%) & S. E & & $p$-value & LSD (5\%) \\
\hline 19.029 & 0.0558 & & 0.0000 & 0.1184 \\
\hline 19.029 & 0.0558 & & 0.0207 & 0.1184 \\
\hline - & 0.0967 & & 0.1899 & - \\
\hline
\end{tabular}




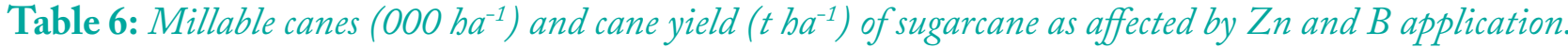

\begin{tabular}{|c|c|c|c|c|c|c|c|c|}
\hline \multirow[t]{3}{*}{ Zinc levels } & \multicolumn{4}{|c|}{ Millable canes $\left(000 \mathrm{ha}^{-1}\right)$} & \multicolumn{4}{|c|}{ Cane yield $\left(\mathrm{t} \mathrm{ha}^{-1}\right)$} \\
\hline & \multicolumn{4}{|c|}{ Boron levels } & \multicolumn{4}{|c|}{ Boron levels } \\
\hline & $0 \mathrm{~kg} \mathrm{ha}^{-1}$ & $1 \mathrm{~kg} \mathrm{ha}^{-1}$ & $0.1 \%$ & Mean & $0 \mathrm{~kg} \mathrm{ha}^{-1}$ & $1 \mathrm{~kg} \mathrm{ha}^{-1}$ & $0.1 \%$ & Mean \\
\hline $0 \mathrm{~kg} \mathrm{ha}^{-1}$ & 63.3 & 75.3 & 85.3 & $74.6 \mathrm{c}$ & $58.0 \mathrm{f}$ & $72.7 \mathrm{e}$ & $90.3 \mathrm{~d}$ & $73.7 \mathrm{c}$ \\
\hline $15 \mathrm{~kg} \mathrm{ha}^{-1}$ & 100.7 & 117.7 & 111.7 & $110.0 \mathrm{a}$ & $102.0 \mathrm{c}$ & $114.7 \mathrm{a}$ & $119.0 \mathrm{a}$ & $111.9 \mathrm{a}$ \\
\hline $0.2 \%$ & 98.0 & 103.0 & 110.3 & $103.8 \mathrm{~b}$ & $100.7 \mathrm{c}$ & $105.0 \mathrm{bc}$ & $113.0 \mathrm{ab}$ & $106.2 \mathrm{~b}$ \\
\hline Mean & $87.3 \mathrm{~b}$ & $98.7 \mathrm{a}$ & $102.4 \mathrm{a}$ & - & $86.9 \mathrm{c}$ & $97.4 \mathrm{~b}$ & $107.4 \mathrm{a}$ & - \\
\hline Variables & S.E & & $p$-value & LSD (5\%) & S. E & & $p$-value & $\operatorname{LSD}(5 \%)$ \\
\hline Zn levels & 2.5060 & & 0.0000 & 5.3124 & 2.6026 & & 0.0000 & 5.5173 \\
\hline B levels & 2.5060 & & 0.0000 & 5.3124 & 2.6026 & & 0.0000 & 5.5173 \\
\hline $\mathrm{Zn} \times \mathrm{B}$ & 4.3404 & & 0.0771 & - & 4.5079 & & 0.0091 & 9.5563 \\
\hline
\end{tabular}

Table 7: Brix and puriy (\%) of sugarcane as affected by Zn and B application.

\section{Zinc levels}

Boron levels

\begin{tabular}{|c|c|c|c|c|c|c|c|c|}
\hline & $0 \mathrm{~kg} \mathrm{ha}^{-1}$ & $1 \mathrm{~kg} \mathrm{ha}^{-1}$ & $0.1 \%$ & Mean & $0 \mathrm{~kg} \mathrm{ha}^{-1}$ & $1 \mathrm{~kg} \mathrm{ha}^{-1}$ & $0.1 \%$ & Mean \\
\hline $0 \mathrm{~kg} \mathrm{ha}^{-1}$ & 17.0 & 19.3 & 20.3 & $18.9 \mathrm{c}$ & $49.7 \mathrm{e}$ & $53.7 \mathrm{e}$ & $69.3 \mathrm{~d}$ & $57.6 \mathrm{c}$ \\
\hline $15 \mathrm{~kg} \mathrm{ha}^{-1}$ & 22.3 & 24.0 & 23.0 & $23.1 \mathrm{a}$ & $74.3 \mathrm{bcd}$ & $84.7 \mathrm{a}$ & $79.3 \mathrm{ab}$ & $79.4 \mathrm{a}$ \\
\hline $0.2 \%$ & 21.3 & 22.0 & 22.3 & $21.9 \mathrm{~b}$ & $71.0 \mathrm{~cd}$ & $75.7 \mathrm{bc}$ & $77.0 \mathrm{bc}$ & $74.6 \mathrm{~b}$ \\
\hline Mean & $20.2 \mathrm{~b}$ & $21.8 \mathrm{a}$ & $21.9 \mathrm{a}$ & - & $65.0 \mathrm{c}$ & $71.4 \mathrm{~b}$ & $75.2 \mathrm{a}$ & - \\
\hline Variables & S. E & & $p$-value & LSD (5\%) & S. E & & $p$-value & $\operatorname{LSD}(5 \%)$ \\
\hline Zn levels & 0.3876 & & 0.0000 & 0.8216 & 1.6355 & & 0.0000 & 3.4671 \\
\hline B levels & 0.3876 & & 0.0000 & 0.8216 & 1.6355 & & 0.0000 & 3.4671 \\
\hline $\mathrm{Zn} \times \mathrm{B}$ & 0.6713 & & 0.0586 & - & 2.8328 & & 0.0009 & 6.0052 \\
\hline
\end{tabular}

\section{Purity (\%)}

Boron levels

\section{Brix (\%)} 6.0052

Table 8: $N$ content (\%) and $K$ content (\%) of sugarcane as affected by $Z n$ and B application.

\begin{tabular}{|c|c|c|c|c|c|c|c|c|}
\hline \multirow[t]{3}{*}{ Zinc levels } & \multicolumn{4}{|c|}{$\mathrm{N}$ content $(\%)$} & \multicolumn{4}{|c|}{$K$ content $(\%)$} \\
\hline & \multicolumn{4}{|c|}{ Boron levels } & \multicolumn{4}{|c|}{ Boron levels } \\
\hline & $0 \mathrm{~kg} \mathrm{ha}^{-1}$ & $1 \mathrm{~kg} \mathrm{ha}^{-1}$ & $0.1 \%$ & Mean & $0 \mathrm{~kg} \mathrm{ha}^{-1}$ & $1 \mathrm{~kg} \mathrm{ha}^{-1}$ & $0.1 \%$ & Mean \\
\hline $0 \mathrm{~kg} \mathrm{ha}^{-1}$ & $0.6 \mathrm{f}$ & $2.0 \mathrm{e}$ & $2.1 \mathrm{cde}$ & $1.6 \mathrm{c}$ & $0.2 \mathrm{f}$ & $0.3 \mathrm{f}$ & $0.4 \mathrm{ef}$ & $0.3 \mathrm{c}$ \\
\hline $15 \mathrm{~kg} \mathrm{ha}^{-1}$ & $2.2 \mathrm{~cd}$ & $2.5 \mathrm{a}$ & $2.4 \mathrm{ab}$ & $2.4 \mathrm{a}$ & $0.5 \mathrm{de}$ & $0.9 \mathrm{a}$ & $0.8 \mathrm{ab}$ & $0.7 \mathrm{a}$ \\
\hline $0.2 \%$ & $2.2 \mathrm{~cd}$ & $2.2 \mathrm{de}$ & $2.3 \mathrm{bc}$ & $2.2 \mathrm{~b}$ & $0.5 \mathrm{de}$ & $0.6 \mathrm{~cd}$ & $0.7 \mathrm{bc}$ & $0.6 \mathrm{~b}$ \\
\hline Mean & $1.7 \mathrm{~b}$ & $2.2 \mathrm{a}$ & $2.3 \mathrm{a}$ & - & $0.4 \mathrm{~b}$ & $0.6 \mathrm{a}$ & $0.6 \mathrm{a}$ & - \\
\hline Variables & S.E & & $p$-value & LSD (5\%) & S.E & & $p$-value & LSD (5\%) \\
\hline Zn levels & 0.0493 & & 0.0000 & 0.1045 & 0.0411 & & 0.0000 & 0.0871 \\
\hline B levels & 0.0493 & & 0.0000 & 0.1045 & 0.0411 & & 0.0001 & 0.0871 \\
\hline $\mathrm{Zn} \times \mathrm{B}$ & 0.0853 & & 0.0000 & 0.1809 & 0.0711 & & 0.0255 & 0.1508 \\
\hline
\end{tabular}

Table 9: $Z n$ content $\left(u g g^{-1}\right)$ and B content $\left(u g g^{-1}\right)$ of sugarcane as affected by $Z n$ and B application.

Zinc levels

\begin{tabular}{|c|c|c|c|}
\hline & \multicolumn{3}{|c|}{ Boron levels } \\
\hline & $0 \mathrm{~kg} \mathrm{ha}^{-1}$ & $1 \mathrm{~kg} \mathrm{ha}^{-1}$ & $0.1 \%$ \\
\hline $0 \mathrm{~kg} \mathrm{ha}^{-1}$ & $0.9 \mathrm{f}$ & $4.3 \mathrm{ef}$ & $5.0 \mathrm{e}$ \\
\hline $15 \mathrm{~kg} \mathrm{ha}^{-1}$ & $60.5 \mathrm{~d}$ & $73.9 \mathrm{a}$ & $71.0 \mathrm{ab}$ \\
\hline $0.2 \%$ & $58.8 \mathrm{~d}$ & $67.1 \mathrm{c}$ & $67.7 \mathrm{bc}$ \\
\hline Mean & $40.1 \mathrm{~b}$ & $48.4 \mathrm{a}$ & $47.9 \mathrm{a}$ \\
\hline Variables & S. E & & $p$-value \\
\hline Zn levels & 1.0431 & & 0.0000 \\
\hline B levels & 1.0431 & & 0.0000 \\
\hline $\mathrm{Zn} \times \mathrm{B}$ & 1.8068 & & 0.0165 \\
\hline
\end{tabular}

\section{$\mathrm{Zn}$ content ( $\left.\mathrm{ug} \mathrm{g}^{-1}\right)$}

Boron levels

June 2020 | Volume 36 | Issue 2 | Page 466
$B$ content (ug g $\left.\mathbf{g}^{-1}\right)$

Boron levels

$\begin{array}{lllll}\text { Mean } & \mathbf{0 ~ k g ~ h a} & \mathbf{1} \mathbf{k g ~ h a}^{-1} & \mathbf{0 . 1 \%} & \text { Mean } \\ 3.4 \mathrm{c} & 0.4 \mathrm{~g} & 5.7 \mathrm{f} & 12.1 \mathrm{e} & 6.1 \mathrm{c} \\ 68.5 \mathrm{a} & 27.6 \mathrm{c} & 35.0 \mathrm{a} & 32.4 \mathrm{ab} & 31.7 \mathrm{a} \\ 64.5 \mathrm{~b} & 24.0 \mathrm{~d} & 27.9 \mathrm{c} & 29.8 \mathrm{bc} & 27.2 \mathrm{~b} \\ - & 17.3 \mathrm{c} & 22.9 \mathrm{~b} & 24.8 \mathrm{a} & \\ \text { LSD (5\%) } & \text { S. E } & & \boldsymbol{P}^{\text {-value }} & \text { LSD (5\%) } \\ 2.2114 & 0.7599 & & 0.0000 & 1.6109 \\ 2.2114 & 0.7599 & & 0.0000 & 1.6109 \\ 3.8302 & 1.3161 & & 0.0016 & 2.7901\end{array}$


Quality parameters

Brix (\%) and purity (\%) both responded significntly $(p<0.05)$ to $\mathrm{Zn}$ end B levels, their interaction for brix was significant, however, interactive effects for purity was nonsignifcant $(p>0.05)$ (Table 7$)$. Zn $15 \mathrm{k} \cdot \mathrm{g} \mathrm{h}^{-1}$ gave highest brix and purity followed by $0.2 \% \mathrm{Zn}$ foliar application having statistical consensus with each other while lowest brix and purity was observed in 0 $\mathrm{k} . \mathrm{g} \mathrm{h}^{-1} \mathrm{Zn}$. Boron $0.1 \%$ foliar application demonstrated greatest brix and puritys econded by $1 \mathrm{k} \cdot \mathrm{g} \mathrm{h}^{-1} \mathrm{~B}$ and $0 \mathrm{~kg} \mathrm{~B} \mathrm{ha}{ }^{-1}$. The interaction of $\mathrm{Zn} 15 \mathrm{~kg} \mathrm{ha}^{-1} \times \mathrm{B} 1 \mathrm{~kg}$ $\mathrm{ha}^{-1}$ exposed improved brix and purityheaded by $\mathrm{Zn}$ $15 \mathrm{k} . \mathrm{g} \mathrm{h} \mathrm{h}^{-1} \times \mathrm{B} 0.1 \%$ whereas moderate results were recorded in $\mathrm{Zn} 0 \mathrm{~kg} \mathrm{ha} \mathrm{h}^{-1} \times \mathrm{B} 0 \mathrm{~kg} \mathrm{ha}^{-1}$. The promising reason of greater quality attributes were favorably due to the zinc which is key constituent of many enzymes and proteins. Singh et al. (1997) too perceived an increase in brix content of sugarcane, when zinc was applied as a basal dose. Thangavelu (2007) observed that $\mathrm{Zn}$ fertilization in addition to NPK considerably increases brix and pol \% juice of cane as compared to those with zero fertilizers or supplied most effective with NPK. Dhanasekaran and Bhuvaneswari (2004) also noticed that percent purity of cane juice significantly increased when $\mathrm{Zn}$ and Fe was implemented both alone and in combination.

\section{Nutrient content parameters}

The perusal of data showed that $\mathrm{N}$ content (\%), $\mathrm{K}$ content (\%), $\mathrm{Zn}$ content $\left(\mathrm{ug} \mathrm{g}^{-1}\right), \mathrm{B}$ content $\left(\mathrm{ug} \mathrm{g}^{-1}\right)$ has been significantly $(p<0.05)$ affected by $\mathrm{Zn}, \mathrm{B}$ and their interaction (Tables 8 and 9). Zn $15 \mathrm{k.g} \mathrm{h}{ }^{-1}$ gave highest $\mathrm{N}, \mathrm{K}, \mathrm{Zn}$ and B content followed by $0.2 \% \mathrm{Zn}$ foliar application having statistical equality with each other while lowest $\mathrm{N}, \mathrm{K}, \mathrm{Zn}$ and $\mathrm{B}$ content was noticed in 0 $\mathrm{k} . \mathrm{g} \mathrm{h}{ }^{-1} \mathrm{Zn}$. B $0.1 \%$ foliar application proceeded with greatest $\mathrm{N}, \mathrm{K}$ and $\mathrm{B}$ content followed by $1 \mathrm{~kg} \mathrm{ha}^{-1} \mathrm{~B}$ and $0 \mathrm{~kg} \mathrm{~B} \mathrm{ha}{ }^{-1}$. In case of $\mathrm{Zn}$ content $\mathrm{B} 1 \mathrm{k.g} \mathrm{h}{ }^{-1}$ gave highest results followed by B $0.1 \%$ foliar application, while least was observed in $0 \mathrm{k} \cdot \mathrm{g} \mathrm{h}^{-1} \mathrm{~B}$. The interaction of $\mathrm{Zn} 15 \mathrm{k.g} \mathrm{h}{ }^{-1} \times \mathrm{B} 1 \mathrm{k} \cdot \mathrm{g} \mathrm{h}^{-1}$ induced improved N, $\mathrm{K}, \mathrm{Zn}$ and $\mathrm{B}$ content lead by $\mathrm{Zn} 15 \mathrm{k.g} \mathrm{h} \mathrm{h}^{-1} \times \mathrm{B} 0.1 \%$ whereas reduced results were recorded in $\mathrm{Zn} 0 \mathrm{k} . \mathrm{g} \mathrm{h}^{-1}$ $\times \mathrm{B} 0 \mathrm{k} \cdot \mathrm{g} \mathrm{h}^{-1}$. The interaction of $\mathrm{Zn} 15 \mathrm{k} \cdot \mathrm{g} \mathrm{h}^{-1} \times \mathrm{B} 1 \mathrm{k} \cdot \mathrm{g}$ $\mathrm{h}^{-1}$ produced superior $\mathrm{N}, \mathrm{K}, \mathrm{Zn}$ and $\mathrm{B}$ content pursued by $\mathrm{Zn} 15 \mathrm{k} \cdot \mathrm{g} \mathrm{h}^{-1} \times \mathrm{B} 0.1 \%$ whereas dwindled results had been recorded in $\mathrm{Zn} 0 \mathrm{~kg} \mathrm{ha}^{-1} \times \mathrm{B} 0 \mathrm{~kg} \mathrm{ha}^{-1}$.The possible reason of superior nutrient content parameters might be due to part of $\mathrm{Zn}$ as it is an critical aspect of different enzyme that are responsible for driving many metabolic reactions in all crops.

\section{Conclusions and Recommendations}

Growthe, yiield, and qualiity of sugarcune were affected significntly by $\mathrm{Zn}, \mathrm{B}$ applicatin and their interaction. $\mathrm{Zn} 15 \mathrm{~kg} \mathrm{ha}{ }^{-1}$ (Soil application) conferred enhanced cane yield $\left(\mathrm{t} \mathrm{ha}^{-1}\right)$ and brix (\%). Foliar application of boron $0.1 \%$ resultd in highest cene yield $(\mathrm{t}$ $\mathrm{h}^{-1}$ ) and Brix (\%). Interaction of $\mathrm{Zn} 15 \mathrm{~kg} \mathrm{ha}^{-1} \times 0.1 \%$ $\mathrm{B}$ proved appropriate for improved yield and quality of sugarcane.

\section{Acknowledgements}

This is exceptional research article and arranged from $\mathrm{PhD}$ thesis work conducted at Sindh Agriculture University, Tandojam, Pakistan.

\section{Novelty Statement}

Little research work has been done on effects of $Z$ inc and Boron on sugarcane particularly in our conditions. This research will help in understanding the role of Zinc and Boron in sugarcane.

\section{Author's Contribution}

N. Mangrio designed and performed overall process of study. M.N. Kandhro guided scholar throughout experiment and write-up process. A.A. Soomro contributed in data analysis and writing of manuscript. N. Mari provided facility for experiment and helped in collection of data. Z.H. Shah contributed in interpretation of results and preparation of research article.

\section{Conflict of interest}

The authors have declared no conflict of interest.

\section{References}

Baloch, S.M.,I.H. Shah,I.Hussain and K.Abdullah. 2002. Low sugar production in Pakistan causes and remedies. Pak. Sugar J., 17: 13-14.

Chandra, K. 2005. Response of foliar application of zinc sulphate, muriate of potash and potassium nitrate on growth, yield and quality of sugarcane ratoon under rainfed situation. Ind. Sugar, 55: 41-44.

Dhanasekaran, K. and R. Bhuvaneswari. 2004. Effect of zinc and iron humates application on the yield and quality of sugarcane. Ind. Sugar, 
54: 95-102.

Ehsanullah, S., Anjum, S.A. Raza, M.M. Riaz, A. Abbas, M.M. Yousif and Y. Xu. 2016. Optimizing row spacing to ameliorate the productivity of spring sugarcane (Saccarum officinarum L.). Agric. Sci., 7(08): 531-538. https://doi.org/10.4236/as.2016.78053

FAO. 2017. Statistical database. Food and Agriculture Organization.

Ghaffar, A., N. Akbar, S.H. Khan, K. Jabran, R.Q. Hashmi, A. Iqbal and M.A. Ali. 2012. Effect of trench spacing and micronutrients on growth and yield of sugarcane (Saccharum officinarum L.). Aust. J. Crop Sci., 6(1): 1-9.

Ghaffar, A., E.N. Akbar and S.H. Khan. 2011. Influence of zinc and iron on yield and quality of sugarcane planted under various trench spacing. Pak. J. Agric. Sci., 48(3): 25-33.

GoP. 2017. Pakistan economic survey, 2016-17. Ministry of food and agriculture. Fed. Bur. Stat., Islamabad, Pakistan.

GoP. 2018. Pakistan economic survey, 2017-18. Ministry of Food and Agriculture. Fed. Bur. Stat., Islamabad, Pakistan.

Hussain, S., M. Anwar-ul-Haq, S. Hussain, Z. Akram, M. Afzal and I. Shabbir. 2015. Best suited timing schedule of inorganic NPK fertilizers and its effect on qualitative and quantitative attributes of spring sown sugarcane (Saccharum officinarum L.). J. Soc. Agric. Sci., 15(2): 187-191.

Jabran, K., Z.A. Cheema, M. Farooq, M.B. Khan. 2017. Fertigation and foliar application of fertilizers alone and in combination with Brassica campestris (L.) extracts enhances yield in wheat crop. Crop. Environ., 2: 42-45.

Keren, R., 1996. Boron. In: (Eds.): Sparks, D.L., A.L. Page, P.A. Helmke, R.H. Loeppert, P.N. Soltanpour, M.A. Tabatabai, C.T. Johnston and M.E. Sumner. Methods of Soil Analysis, Part 3: Chemical Methods. Soil Sci. Soc. Am. Madison, WI, USA.

Khan, K.S., S. Rehman, G. Ahmad, D. Khan and G. Rehman. 1997. Effect of foliar application of micronutrients on the yield and yield components of sugarcane. Proc. $32^{\text {nd }}$ Ann. Conv. Pak. Soc. Sug. Tech. Rawalpindi.

Lifang, H., S. Fan, F. Libo and Z. Zongsheng. 2001. Effects of phosphorus, potassium, sulfur, and magnesium on sugar cane yield and quality in Yunnan. Better Crops Int., 15(1): 6-10.
Madhuri, N., K.V. Sarala, N.V.H. Kumar, M.S. Rao and V. Giridhar. 2016. Influence of micronutrients on yield and quality of sugarcane. Sugar Technol., 15(2): 187-191. https://doi. org/10.1007/s12355-012-0196-3

Malik, K.B., and M.H. Gurmani. 2005. Cane Production guide. Dewan farooque sugarcane research institute, dewan city. pp. 38-41.

Mariano, F.H., E. Vitti, A. Faroni, C. Otto and R.T. Paulo. 2011. Sugarcane response to boron and zinc in Southeastern Brazil. Sugar Technol., 13 (1): 86-95. https://doi.org/10.1007/s12355010-0057-x

Mazhar, S., 2016. Impact of zinc and boron application on growth, cane yield and recovery in sugarcane. Life Sci. Int. J. 10: 30-37.

MNFSR. 2013. Year book 2012-13. Islamabad: MNFSR (Ministry of national food security and research), Government of Pakistan.

Naemat, A.A., A. El-Gawad, A.N. El-Din, I.H. El-Geddawi and N.B. Azazy. 1992. Effect of nitrogen and zinc application on growth criteria of sugarcane plants. Pak. J. Sugar. 6(1): 3-10.

Naqvi, H.A., 2005. In: Pakistan sugar book. Pak. Soc. Sugar Technol. Mandi Bahaudin, Punjab, Pakistan.

Panhwar, R.N., H.K. Keerio, Y.M. Memon, S. Junejo, M.Y. Arain, M. Chohan, A.R. Keerio and B.A. Abro. 2003. Response of Thatta-10 sugarcane variety to soil and foliar application of zinc sulphate $(\mathrm{ZnSO} 4,7 \mathrm{H} 2 \mathrm{O})$ under half and full doses of NPK fertilizer. Pak. J. Appl. Sci., 3(4): 266-269. https://doi.org/10.3923/ jas.2003.266.269

Rayan, J., G. Estefan and A. Rashid. 2001. Soil and plant analysis laboratory manual. Int. Center Agric. Res. Dry Areas (ICARDA), Aleppo, Syria. pp. 172.

Rohtash, K., and P.P. Singh. 1997. Effect of phosphorus and zinc nutrition on yield attributes of sugarcane in calcareous soil of foothill region of Uttar Pradesh. Ind. J. Agron., 42: 702-704.

Singh, V.H., A. Kumari and A.P. Singh. 1997. Zinc management in sugarcane under calcareous soil. In: Proc. 59 $9^{\text {th }}$ Annu. Conv. Suger Technol. Assoc. Ind., Goa, Ind. pp. 49-58.

Shafique, M., 2015. Impact of zinc and boron application on grwoth, cane yield and recovery in sugarcane. Life Sci. Int. J., 10(01): 30-37.

Soomro, F.M., M.B. Bhatti, M.H. Leghari, G.H. Jamro and M.I. Kumbhar. 2005. Growth and 
yield of sugarcane variety $\mathrm{Cp}-65 / 357$ as affected by foliar feeding of micronutrients. Indus Bio. Sci. 2(2): 211-218.

Statistix. 2006. Statistix 8.1 user guide, version 1.0. Analytical Software, PO Box 12185, Tallahassee FL 32317 USA. Copyright 2006 by Analytical Software.

Thangavelu, S., 2007. Zinc and sugarcane production. Rev. Ind. Sugar, 57: 39-46.

Tunio, S.P., A.M. Kumbhar, S. Junejo and G.H. Jamro. 2004. Effect of micronutrients on sugarcane tillering and millable canes. Indus J. Plant Sci., 3(4): 426-432.
Walkley, A. and I. A. Black. 1934. An examination of degtjareff method for determining soil organic matter and a proposed modification of the chromic acid titration method. Soil Sci., 37:29-37.

Wang, J.J., C.W. Kennedy, H.P. Viator, A.E. Arceneaux and A.J. Guidry. 2005. Zinc fertilization of sugarcane in acid and calcareous soils. J. Am. Soc. Sugar Technol., 25: 4961.

Wright, R.J., and T. Stuczynski. 1996. Atomic Absorption and Flame Emission Spectrometry. In: (Ed.): Sparks, D.L. methods of soil analysis: Part 3. Chem., Methods Soil Sci. Soc. Am. Book Ser. 5. SSSA-ASA, Madison WI. pp. 63-65. 